\title{
Larval development of Spodoptera eridania and Spodoptera frugiperda fed on fresh ear of field corn expressing the Bt proteins (Cry1F and Cry1F + Cry1A.105 + Cry2Ab2)
}

\author{
Desenvolvimento larval de Spodoptera eridania e Spodoptera frugiperda alimentadas com espigas de \\ milho verde expressando proteínas $B t$ (Cry1F e Cry1F + Cry1A.105 + Cry2Ab2)
}

\author{
Orcial Ceolin Bortolotto ${ }^{I}$ Adeney de Freitas Bueno ${ }^{\text {II }}$ \\ Ana Paula de Queiroz ${ }^{\text {III }}$ Gabriela Vieira Silva ${ }^{\text {IV }}$
}

\begin{abstract}
The objective of this study was to evaluate extent of larval period, larval survival (\%), food consumption, and pupal biomass of Spodoptera eridania and Spodoptera frugiperda (Lepidoptera: Noctuidae) fed on fresh ears of field corn expressing Bt proteins (CrylF and CrylF+Cry1A.105+Cry2Ab2). Larvae of Spodoptera spp. survived less than two days when they consumed Bt corncobs and showed 100\% mortality. Spodoptera eridania reared on non-Bt corn cobs showed higher larval development (21.6 days) than S. frugiperda (18.4 days) and lower viability $(56.4 \%$ and $80.2 \%$ for $\boldsymbol{S}$. eridania and $\boldsymbol{S}$. frugiperda, respectively). A higher amount of corn grains was consumed by $\boldsymbol{S}$. eridania (5.4g) than by $\boldsymbol{S}$. frugiperda (3.9g). In summary, this study demonstrated that the toxins CrylF and CrylF + Cry1A.105 + Cry2Ab2 expressed in fresh corn cobs contributed to protect ears of corn against $\boldsymbol{S}$. frugiperda and the non-target pest $\boldsymbol{S}$. eridania. However, itis important to monitor non-Bt cornfields because of the potential of both species to cause damage to ear sof corn.
\end{abstract}

- NOTE
Key words: biology, integrated pest management, fall armyworm, Southern armyworm, varietal resistance.

RESUMO

Este estudo teve como objetivo avaliar o periodo de desenvolvimento larval, sobrevivência larval (\%), consumo de alimento e biomassa pupalde Spodoptera eridania e Spodoptera frugiperda (Lepidoptera: Noctuidae), alimentadas com grãos verdes de milho Bt que expressam as proteinas CrylF e CrylF + Cry1A.105 + Cry2Ab2). As larvas de Spodoptera spp. alimentadas com milho Bt sobreviveram por até dois dias, registrando-se $100 \%$ de mortalidade. A espécie $S$. eridania alimentada com grãos de milho não Bt apresentou um maior desenvolvimento larval (21,6 dias) do que S. frugiperda (18,4 dias), e menor viabilidade larval
(56,4\% e 80,2\% para $\boldsymbol{S}$. eridania e $\boldsymbol{S}$. frugiperda respectivamente). Uma maior taxa de consumo de grãos foi observada para $\boldsymbol{S}$. eridania $(5,4 g)$ do que para $S$. frugiperda $(3,9 g)$. Em sintese, este estudo comprova que as toxinas CrylF e CrylF + CrylA.105 Cry2Ab2 expressas em grãos imaturos de milho contribuem na proteção das espigas de milho contra $\boldsymbol{S}$. frugiperda e a praga nãoalvo $\boldsymbol{S}$. eridania, entretanto, é importante monitorar as lavouras cultivadas com milho não Bt, devido o potencial de ambas as espécies em ocasionar danos nas espigas da planta.

Palavras-chave: biologia, manejo itegrado de pragas, lagartado-cartucho, lagarta-das-vagens, resistência varietal.

For integrated pest management (IPM), the use ofresistant genetically modified organisms (GMOs) contributes in reducing the insecticides applications and environ mental impact. Cultivation of improved plants that express the insecticidal gene cry via the bacterium Bacillus thuringiensis Berliner $(B t)$ is performed almost worldwide (JAMES, 2013). Efficiency of the Cry1F protein for controlling Spodoptera frugiperda (Lepidoptera: Noctuidae) has been reported (BUNTIN, 2008; SIEBERT et al., 2008), but it was observed when only maize leaves were offered. Recently, BORTOLOTTO et al. (2015) reported the slightly poor development of Spodoptera eridania (Lepidoptera: Noctuidae) when fed with maize leaves that expressed single Cry $1 \mathrm{~F}$ and pyramided

'Departamento de Agronomia, Universidade Estadual do Centro Oeste (UNICENTRO), Campus CEDETEG, Rua Simeão Camargo Varela de Sá, 03, Vila Carli, 85040-080, Guarapuava, PR, Brasil. E-mail: bortolotto.orcial@gmail.com. Corresponding author.

IEmbrapa Soja, Londrina, PR, Brasil.

IIIniversidade Federal do Paraná (UFPR), Curitiba, PR, Brasil.

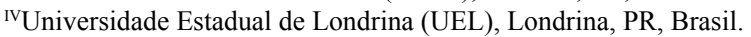


Cry1F + Cry1A.105 + Cry2Ab2 insecticidal proteins; however, the impactof these $B t$ proteins remains unclearbecause of high larval mortality even when non-Bt maize leaves were offered.

Spodoptera spp. can damage the reproductive structures of plants (KING \& SAUNDERS, 1984), and there is little information on the development of the Spodoptera complex in corncobs; studies are required to formulate implementation strategies for IPM. In this study, we aimed to assess the impact of the $B t$ protein Cry1F and pyramided protein Cry1F + Cry1A.105 + Cry2Ab2 expressed in fresh corncobs on the larval development of $\boldsymbol{S}$. eridania and $\boldsymbol{S}$. frugiperda.

The study was performed in the entomology laboratory of Embrapa Soybean, and the experiments were performed using BOD type climatic chambers under the following controlled environmental conditions: temperature, $25 \pm 2^{\circ} \mathrm{C}$; relative humidity, $60 \pm 10 \%$; and photoperiod, $14 / 10 \mathrm{~h}$ (L/D). Larvae of S. eridania and $S$. frugiperda were obtained by mass insect rearing at Embrapa Soybean, where the insects were reared for about 20 generations.

The two $B t$ corn isolines used in the study were as follows: Herculex ${ }^{\circledR}$ I (event TC1507), which contained the gene for the insecticidal protein Cry $1 \mathrm{~F}$, and genotype PowerCore ${ }^{\circledR}$ (event MON89034 x MON00603 x DAS01507), which contained five genes with stacking traits that code for three different Bt proteins (Cry1F + Cry1A.105 + Cry2Ab2) with insecticidal effects and two genes (PAT + EPSPS) that code for tolerance to the herbicides glyphosate and glufosinate. The non- $B t$ isoline used was genotype 2B688 DOW. Sowing of corn genotypes was performed in a greenhouse. After seedling emergence, irrigation was performed daily. Chemical fertilization was performed according to the regional recommendation (FANCELLI \& DOURADONETO, 2000). Corncobs were harvested in the dough stage (paste-like) and immediately peeled to feed $\boldsymbol{S}$. eridania and $S$. frugiperda larvae.

Comparison of the biological aspects of S. eridania and $\boldsymbol{S}$. frugiperda larvae was carried out using a completely randomized experimental design, with three treatments (two isogenic Bt corn genotypes and one non-Bt corn genotype) and 11 replications. Each replicate was composed of eight larvae. Newly hatched larvae (until 24 hours of age) were individually addedusing a thin-tip brush $(0.6 \mathrm{~mm})$ into paraffin cups (capacity, 50ml) for each treatment, resulting in a total of 88 larvae for each treatment. Larvae for each replicate were fed with pieces of fresh corncobs prepared previously (treatments).
Fresh corncobs were husked and sliced into pieces for the larvae. The food was replaced daily at the same time, and larval instar and larvae mortality rate were assessed daily until the larvae reached the pupal stage.

When the larvae reached the fifth instar stage, consumption of corn grains was assessed by the weight difference of corncobs sliced before feeding and the weight of the same corncobs $24 \mathrm{~h}$ after feeding. Pieces of corncobs were weighed before they were offered to the fifth instar larvae to verify the consumption rate, and the weight of food consumed was corrected with the value obtained for the weight of corn grains used in the control treatment (without larva) to assess the weight lost by the grains due to dehydration. Larvae were fedwith fresh corn grains ad libitum until they completed the larval phase, i.e., until the pre-pupal phase. Results obtained for S. eridania larvae were then comparedwith those obtained for $\boldsymbol{S}$. frugiperda larvae. Within $24 \mathrm{~h}$ after the larvae reached thepupal stage, the individuals were weighedusing an analytical balance with $0.001 \mathrm{~g}$ of precision. Parameters assessed for both species were as follows: extent of the larval period (days); larval survival (\%); grain consumption (g); and pupal biomass $(\mathrm{g})$.

Results of the different bioassays were subjected to exploratory analysis to assess the assumptions of normality of residuals, homogeneity of variance of treatment, and additivity of the model to allow for application of analysis of variance. Mean values were compared using Tukey's test. To compare biological parameters and grain consumption, Student' st-test was used. For both tests, the difference was considered significant only when the significance level was equal to $\mathrm{P} \leq 0.05$.

This study demonstrated $100 \%$ mortality for $\boldsymbol{S}$. eridania and $\boldsymbol{S}$. frugiperda fed on fresh grains to both $B t$ events with expression of a single (Cry1F) and pyramided event (Cry1F + Cry1A.105 + Cry2Ab2) (Table 1). Thus, although $\mathbf{S}$. eridania is a non-target pest, these proteins act againstits development. When larvae were fed with fresh grains of the non- $B t$ corn genotype, a large percentage of the larvae were able to complete larval stage; this indicates that the grains are nutritionally suitable for the development of $\boldsymbol{S}$. eridania larvae. This is an important observation because $\boldsymbol{S}$. eridania larvae has a poor development when fed on maize leaves (BORTOLOTTO et al., 2015). Higher corn cob consumption by $\boldsymbol{S}$. eridania rather than by $\boldsymbol{S}$. frugiperda was observed, but lower pupal biomass was reported for $\boldsymbol{S}$. eridania. Nevertheless, the pupal biomass of $\boldsymbol{S}$. eridania collected in the present 
Table 1 - Biological aspects of Spodoptera eridania and Spodoptera frugiperda (Lepidoptera: Noctuidae) fed with Bt and non-Bt fresh corncobs.

\begin{tabular}{|c|c|c|c|c|}
\hline Treatment & Larval period (days) $^{1}$ & Survival $(\%)^{1}$ & $\begin{array}{l}\text { Consumption } \\
\text { of corn cobs }(\mathrm{g})^{2}\end{array}$ & Biomass pupal $(\mathrm{g})^{2}$ \\
\hline S. eridania on non-Bt isogenic (DOW 2B688) & $21.6 \pm 0.7 \mathrm{a}$ & $56.4 \pm 6.8 \mathrm{~b}$ & $5.4 \pm 0.3 \mathrm{a}$ & $0.26 \pm 0.1 \mathrm{~b}$ \\
\hline S. frugiperda on non- $B t$ isogenic (DOW 2B688) & $18.4 \pm 0,8 b$ & $80.2 \pm 5.2 \mathrm{a}$ & $3.9 \pm 0.3 \mathrm{~b}$ & $0.29 \pm 0.1 \mathrm{a}$ \\
\hline S. eridania on Cry1F & $1.1 \pm 0.5 \mathrm{c}$ & $0.0 \pm 0.0 \mathrm{c}$ & $3^{3}-$ & - \\
\hline S. frugiperda on Cry1F & $1.6 \pm 0,9 \mathrm{c}$ & $0.0 \pm 0.0 \mathrm{c}$ & - & - \\
\hline S. eridania on Cry1F + Cry1A. $105+$ Cry 2 Ab2 & $0.9 \pm 0.5 \mathrm{c}$ & $0.0 \pm 0.0 \mathrm{c}$ & - & - \\
\hline S. frugiperda on Cry1F + Cry1A. $105+$ Cry $2 \mathrm{Ab} 2$ & $1.3 \pm 0.8 \mathrm{c}$ & $0.0 \pm 0.0 \mathrm{c}$ & - & - \\
\hline $\mathrm{CV}(\%)$ & 5.31 & 11.49 & 15.4 & 6.6 \\
\hline DF residual & 24 & 24 & 8 & 8 \\
\hline $\mathrm{F}$ & 42.8 & 91.32 & 10.3 & 7.3 \\
\hline $\mathrm{P}$ & $\leq 0.05$ & $\leq 0.05$ & $\leq 0.05$ & $\leq 0.05$ \\
\hline
\end{tabular}

${ }^{1}$ Means \pm SEM followed by the same letter in the same stage of development of the insect column do not differ by Tukey test (P $\left.\leq 0.05\right)$. ${ }^{2}$ Means \pm SEM followed by the same letter in the column do not differ by $t$-test $(\mathrm{P} \leq 0.05)$.

${ }^{3}$ Parameter non existent.

study is similar to that of $\boldsymbol{S}$. eridania observed on suitable hosts, such as cotton bolls and morning glory (SANTOS et al., 2005). So, is possible that the higher consumption of corncobs might be associated with toxins or nutritional imbalance present in the food (LARA, 1991), suggesting a poor quality to larval development of $\boldsymbol{S}$. eridania. In this sense, the lower pupal biomass of $\boldsymbol{S}$. frugiperda could be attributed to the biological differences between the species and adaptation to consume ears of field corn.

Efficiency of Cry1F protein in controlling

S. frugiperda has been reported in other studies (BUNTIN, 2008; SIEBERT et al., 2008), but it was observed when to $\boldsymbol{S}$. frugiperda were offered corn leaves only. There fore, this is the first study in which insecticide proteins (single Cry1F and pyramided Cry1F + Cry1A.105 + Cry2Ab2) expressed in fresh corncobs helped to kill $\boldsymbol{S}$. frugiperda like thenon-target pest $\boldsymbol{S}$. eridania. There wasgenetic variability in different populations that can show resistance to maize $B t$. For example, FARIAS et al. (2014) recently reported $\boldsymbol{S}$. frugiperda populations that were resistant against Cry $1 \mathrm{~F}$ protein expressed in corn leaves. It is crucial to adopt integrated resistance management IRM, monitoring pest infestation in crop fields, and adoptinga refuge area to less risks of increase resistance.

Overall, although both $B t$ events showed similar effects in Spodoptera spp. larvae, it is usually recommended to prefer pyramided events because of the low risk of resistant development. This is reinforced by a previous study that showed reduced damage of corncobs by $\boldsymbol{S}$. frugiperda in Bt pyramided (expressing Cry1A.105 e Cry2Ab2) cornfields when compared with single $B t$ corn Cry1A(b) (WAQUIL et al., 2013). Thus, Bt pyramided corn allowed to reduce the refuge area in which the number of pests that survive is lower than that in a field which a single $B t$ corn has been cultivated (SIEBERT, 2012). Finally, this study indicated that Cry1F and Cry1F + Cry1A.105 + Cry2Ab2 expressed in corncobs helped to control $\boldsymbol{S}$. eridania and $\boldsymbol{S}$. frugiperda larvae. However, non- $B t$ corn fields should be constantly monitored, since these larvae have the potential to damage corn plants.

\section{ACKNOWLEDGEMENTS}

Authors wish to thank Embrapa Soybean, the sponsor agencies Coordenação de Aperfeiçoamento de Pessoal de Nível Superior (CAPES) and Conselho Nacional de Desenvolvimento Científico e Tecnológico (CNPq) for financial support.

\section{REFERENCES}

BORTOLOTTO, O.C. et al. Larval development of Spodoptera eridania (Cramer) fed on leaves of Bt maize expressing Cry1F and Cry1F + Cry1A.105 + Cry2Ab2 proteins and its non-Btisoline. Revista Brasileira de Entomologia, v.59, n.1, p.7-11, 2015.

BUNTIN, G.D. Corn expressing Cry1Ab or Cry1F endo toxin for fall army worm and corn ear worm (Lepidoptera: Noctuidae) manage ment in field corn for grain production. Florida Entomologist, v.91, n.4, p.523-530, 2008. Available from: <http:// journals.fcla.edu/flaent/article/view/75856>. Accessed: Apr. 12, 2015. doi: 10.1653/0015-4040-91.4.523. 
FANCELLI, A.L.; DOURADO-NETO, D. Produção de milho. Guaíba: Agropecuária, 2000. 360p.

FARIAS, J.R. et al. Field-evolved resistance to Cry1F maize by Spodoptera frugiperda (Lepidoptera: Noctuidae) in Brazil. Crop Protection, v.64, s/n, p.150-158, 2014. Available from: <http://www.sciencedirect.com/science/ article/pii/S026121941400204X >. Accessed: Apr. 25, 2015. doi: 10.1016/j.cropro.2014.06.019.

JAMES, C. Global status of commercialized Biotech/GM Crops: 2013. ISAAA: Ithaca, New York: ISAAA, 2013. ISAAA Brief N. 46.

KING, A.B.S.; SAUNDERS, J.L. The invertebrate pests of annual food crops in Central America. London: Overseas Development Administration, 1984. 166p.

LARA, F.M. Princípios de resistência de plantas a insetos. São Paulo: Ícone, 1991. 334p.
SANTOS, K.B. et al. Biologia de Spodoptera eridania (Cramer) (Lepidoptera: Noctuidae) em diferentes hospedeiros. Neotropical Entomology, v.34, n.6, p.903-910, 2005.

SIEBERT, M.W. et al. Efficacy of Cry1F insecticidal protein in maize and cotton for control of fall armyworm (Lepidoptera: Noctuidae). Florida Entomology, v.91, n.4, p.555-564, 2008. Available from: $<$ http://www.bioone.org/doi/pdf/10.1653/0015-4040-91.4.555>. Accessed: Apr. 12, 2015. doi: 10.1653/0015-4040-91.4.555.

SIEBERT, M.W. Evaluation of corn hybrids expressing Cry1F, Cry1A.105, Cry2Ab2, Cry34Ab1/Cry35Ab1, and Cry3Bb1 against southern United States insect pests. Journal of Economic Entomology, v.105, n.5, p.1825-1834, 2012. Available from: $<$ http://www.ncbi.nlm.nih.gov/pubmed/23156183>. Accessed: Apr. 12, 2015. doi: 10.1603/EC12155.

WAQUIL, J.M. et al. Management of Lepidopteran pests in maize crop using the Bt pyramided event Cry1A.105 and Cry2Ab2. Pesquisa Agropecuária Brasileira, v.48, n.12, p.1529-1537, 2013. 